\title{
REPARATION, SLAVERY AND POLITICAL REALISM: THE CHALLENGE OF CONTEMPORARY AFRICAN LEADERSHIP
}

DOI: http://dx.doi.org/10.4314/ft.v5i1.4

\author{
Adeolu Oluwaseyi OYEKAN, MA \\ Department of Philosophy, Lagos State University
}

\begin{abstract}
In spite of some revisionist attempts to rationalise slavery as just another form of trade between interested parties, there is an overwhelming conviction that it represented an age of man's highest inhumanity to fellow man. Accordingly, calls have been loud and persistent as to the need for reparation which though will never compensate for actual loss, nevertheless has the possibility of symbolising penitence and serve as cushion for some of the debilitating damages done. This paper examines the moral basis of the call for reparation. In agreeing with the moral validity of the claims, the paper probes further in a realistic manner and argue that African states in their present situation cannot make a serious case for reparation. The paper argues further that for African states to position themselves for genuine reparation struggles in this age of political realism, urgent steps must be taken to ensure the useful and productive deployment of available resources in Africa and remove the continent from its appendage status with the west. The paper concludes that only when African states are able to break the cycle of poverty and underdevelopment, freeing themselves from external manipulations can a credible and rewarding case for reparation be made.
\end{abstract}

Keywords: Reparation, Slavery, Realism, Africa, Leadership

\section{Introduction}

Two centuries after the slave trade, discourse on its nature, causes and effects continue to draw attention from scholars of various orientations, be it historical, sociological, legal, philosophical and even psychological. The reason for this should not be far-fetched. The African community in Diaspora ranks among the lowest in terms of material well-being, while the African continent remains ravaged by poverty, diseases and strife, making it the least-developed region in the world. Since it is no longer politically correct for a nation, group or individual to hinge development on racial factors, at least publicly, it seems that there is a consensus globally that contra social Darwinism; the black man's predicament is not natural jafter all.

If the above is the case, human factors (conceived from different viewpoints) omust then be responsible for the black man's underdevelopment. Some scholars are $\approx$ of the view that slave trade and colonialism are two key factors responsible for the continent's underdevelopment (FANON 1966; AKE 1996; ONIGBINDE 2003). 
Many are even of the broader view that though the slave trade and colonialism have ended, both have been replaced with a more sophisticated version of imperialism in the guise of capitalism and globalization. Yet, issues arising from slavery and colonialism, of which reparation is one; requires and continues to generate scholarly reactions.

A plethora of historical documentation has been done as far as slavery is concerned. Revisiting this discourse therefore is with a view to revisiting perhaps the most prominent issue it has generated in present times namely - reparation. I wish to briefly examine the meaning of reparation, the case for reparation, the argument against it and the ethical issues involved. Persuaded that the slave trade raises issues of complex ethical and practical dimensions, I shall examine the possibility and consequences of reparation being paid to blacks, especially those of present day Africa.

\section{What is Reparation?}

Reparation is a term which has its roots in Latin reparatio. Literally, the word reparation means the act of renewing, restoring, or the state of being repaired; the act of making amends or giving satisfaction or compensation for a wrong. In this sense, it refers to something done or paid in expiation of an injury inflicted. In another sense, the online History channel (2009) defines it as "compensation paid by countries that start wars in which they are defeated, such as Germany was asked to do after the treaty of Versailles". Reparation has also been defined as including an acknowledgment, atonement and recompense made to Africans on the continent and those in Diaspora (AGHALINO 2000, 9). For Walter Block $(2002,54)$, reparation is the forced return of stolen property. According to John Arthur $(2007,205)$, there is a need to define reparation in a way that distinguishes it from restitution. While both are forms of compensation, restitution occurs when property that has been taken is returned. Reparation on the other hand, is "repair of harms caused by past wrongs done either intentionally or through negligence" (ARTHUR 2007, 205). For Arthur, while restitution focuses on restoring lost property, reparation goes deeper by looking into the issue of harm caused. For our purpose, reparation can be defined as a proposal or agitation that compensation be provided for nations and descendants of enslaved people in consideration of free, forced labour provided over centuries, resulting in losses (both individual and collective); which has been developmentally beneficial to the nations and societies involved in the slave trade.

In talking about reparation, it is important to identify the intended beneficiaries and provide a justification for doing so. For the sake of this paper, I consider the prospective beneficiaries of slavery reparations to be AfricanAmericans, Caribbean nations and African countries with the exclusion of North Africa. To a significant extent, the three categories mentioned above represent those boonded by same historical circumstances of slavery but separated by socio-political ๘developments from which slavery itself cannot be excluded. The first and second refer to the African community in Diaspora and other blacks who by virtue of the 
slave trade became part of a society originally alien to their ancestors. In the second sense, I talk about black nations and their people whose relatives and forefathers were taken away but are still on African soil. The bulk of the first set of people form the descendants of those who made it to the plantation and had the "privilege" to procreate in sustenance not only of their lineage but also the interest of slaveholders constantly in need of more labourers. The second category consist largely of Africans whose forbears lost relatives to slavery, and the descendants of some few who made it back home after the abolition of slave trade among others. Aghalino's definition of reparation is an attempt to capture this classification and the circumstance leading to it. On the other hand, present day northern Africa, while geographically a part of the continent, is too dissimilar in terms of racial category and slave history to come under focus in this work.

The above clarification foreshadows the complexities involved in determining who precisely ought to be compensated and on what ground. However, this must first of all be preceded by the establishment of the ground for reparation in the first place, since it is of little help to determine who ought to be compensated when the rightness or otherwise of reparation remains unresolved.

This much can be appreciated if one considers the complexities of many issues surrounding slavery and the reparation struggle. For instance, there is the issue of the extent to which the United States is guilty as a sovereign state and the level of involvement of those European countries that governed those colonies where slavery was legal. To what extent would America want to be held liable for slavery reparation prior to 1776? Complex as these issues among many others may seem, they do not look strong enough to vitiate the case for reparation, for they involve technicalities which, given the will, can be resolved.

\section{The Arguments against Reparation}

One argument against reparation is that it will only atone for injustice with another injustice. This is hinged on the fact that if reparation should be paid by states, it would mean doing so with the resources not only of those who benefited and took part in slavery, but also of the majority who did not get involved. In affirming the reality of slavery, what this argument seeks to do is highlight the point that not all members of slave-owning societies actually owned slaves. Also, one way of characterizing reparation by those who hold this view is that it is nothing short of reverse racism (see AUTHUR, 2007).

Taken to another level, a strand of the argument says that those who benefited from slave trade have since died, and that holding their descendants responsible would amount to an unjustified transfer of the guilt of their forefathers. Hence, since all slaves and slave-owners are dead, no justifiable payments can be $\checkmark$ made to the descendants of the former by those of the latter (KANE 2003, 196).

Another related argument to the above is that the identification of the actual

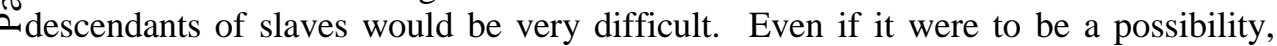
determining the level of victimization would be impossible to identify. The reason, it 
has been said, is because victimization levels are exactly not the same (TRACINSKI 2002). This argument looks plausible on the surface, at least from the complexity of sorting who is a slave descendant from who is not, and inventing a calculus of suffering endured. A corollary of the argument is that there is a problem of how to appropriately measure culpability. For instance, reparation could result in making America pay for the profits of Europeans who merely used part of its lands for plantation.

Another argument canvassed is that slave trade had been in force in Africa before the Europeans discovered this free source of labour. African tribes captured men and women in battle and forced them into slavery and sold them to traders from other countries. By this token, the western world is no guiltier of slave trade than Africans are. However, one can respond to this argument by simply pointing out that slavery as a product of war was not alien to any society. Slavery in that sense was a consequence of war and not the cause of it.

Also, the slave was not a mere commodity or tool in the sense that obtained in foreign plantations. While they were definitely not freemen, many of them were able to buy their freedom or get integrated into their new societies, though with limited privileges. Many European nations warred with each other while the slave trade was on-going. But whereas territories were conquered and oppositions subjugated, Europeans did not convert fellow Europeans to properties as they did to Africans. Even in defeat and exploitation, they were still treated as humans, as opposed to the reduction of black men and women to expendable properties. In the same token, Africans treated captured slaves as humans, such that many of them were able to buy their freedom after a long period of servitude. The Atlantic slave trade was not slavery as usual. It was a new form of slavery far more diabolical than that which existed since ancient times, and far more appalling than the intertribal slavery that existed in Africa prior to the European influence (BROOKS 2006).

Opponents of reparation also defend the argument that slave descendants are better off than they would have been had there been no slave trade. One proponent of such view is Booker Washington who argued that:

when we rid ourselves of prejudice, or racial feeling, and look facts in the face, we must acknowledge that, notwithstanding the cruelty and moral wrong of slavery, the ten million Negro inhabiting this country, who themselves or whose ancestors went through the school of American slavery, are in a stronger and more hopeful condition, materially, intellectually, morally, and religiously, than is true of an equal number of black people in any other portion of the globe.

ᄂ (WASHINGTON 1967, 13)

¿odavid Horowitz (2002) corroborates Washington's position. His own argument is $\widetilde{\sigma}$ that while slave labour has created American wealth, it is not the case that only whites have benefited. Slave descendants have also enjoyed the wealth created 
through forced labour. The fallacies of the above position are so obvious. In his response to some of the reasons advanced against reparation as mentioned above, and elaborated further in Horowitz's Ten Reasons (2002), Walter Block $(2002,59)$ noted that a case can still be made for reparation even if it is true that some blacks aided slavery. All that is required is to add such blacks to the list of those indebted to slaves and their descendants. I think that Block's argument counters very well Horowitz's position because reparation is not being demanded by blacks from whites on the basis of the latter's colour. Rather, it is for the harm done over a very long period of time which requires repair. It sounds plausible then, to widen the net against all culprits irrespective of colour rather than parse over the issue because a few members of same race with the victims are complicit. If this line of thought were to be valid, it should also have stopped the payments of compensations to Jews who suffered losses during the Holocaust, as there are evidences that the Nazis had Jews who supplied them information and worked assiduously for the attainment of Hitler's goal. However, having a collaborator does nothing to take away the guilt of the perpetrator.

Also, that blacks in America are well off in spite of slavery is beside the point. Block captured the argument thus: "Suppose a man rapes a woman, and it is later somehow proven that had he not molested her in this way, she would have instead been run over by a bus and killed. Should this fact mitigate the punishment imposed on him? Not a bit. He is a rapist, and should be punished to the full extent of the law (BLOCK 2002, 60).

It is debatable in the first place whether a people who feel like second class citizens in their own country are better off than blacks in other parts of the world. The discrimination they suffer in schools, workplaces and from law enforcement agents which undermines their dignity as human beings would not really matter in Washington's assessment provided they are better off than blacks elsewhere, at least materially. His position implicitly mirrors the fallacy of white or black (false dilemma).

The argument equally betrays a lack of proper understanding of what it means to be well off, putting aside the fact that being well off if true, is actually an unintended consequence, not the motive of slave trade. Apparently, Horowitz and Washington both had American prosperity in mind while arriving at their conclusion. But then history has shown that being well off materially does not necessarily bring fulfillment. People abound who pass through untold agonies even in the midst of great wealth. But more importantly, these two apologists fail to identify the fact that the helpless picture of blacks elsewhere in the world, which they tried to paint, reflects the tragic consequence of slave trade in the first instance. They did not provide proof that black Americans and their ancestors would still have been worseoff if they had been allowed to grow and develop on their own soil and at their own Eppace.

$\approx \quad$ One can at this point begin to respond to some of the issues raised against the plausibility of paying reparation. To start with, the argument about partial 
culpability of citizens of slave-trading states and the demise of direct beneficiaries sound tenuous. Whereas, it is true that not all members of such societies owned slaves, it would be hard to prove that they did not derive indirect benefits which accrued to their societies as a result of slave trade. If for instance a state decides to go to war, there is always the tendency for opinions to be divided as to the rightness or otherwise of such decision. The consequence of that decision whether good or bad becomes that of the state in entirety irrespective of individual dispositions. Culpability has a sufficient ground of being established by membership of a society which embraced and benefitted from slave trade. The position that descendants cannot pay for the crime of their forbears is also weak. This argument is weak mainly in the sense that a society exists in a continuum. The point is that the contribution of slave labour to American and European economic growth cannot be denied, and that the benefits contribute a large part of what is responsible for the present level of development enjoyed by those nations. Many scholars (LEWAN \& BARCLAY 2001; WINBUSH 2003; GROSSMAN 1997) have identified acts such as forceful takeover of black properties, in some cases referred to as whitecapping" in the Jim Crow era, as acts of deprivation, assault, and in some cases killing, meted out to blacks even after slavery was outlawed. There is equally the issue of private corporations who were involved in slave trade. There were for example, insurance companies writing life insurances on the lives of the slaves, with the slave owners as beneficiaries. These companies made profits, with corresponding tax obligations paid to government at various levels. According to Feagin the damages done to African Americans did not end with slavery, but persisted for another one hundred years in the form of legal segregation, and then for several more decades in present-day discrimination (FEAGIN 2004, 53). The first African slaves arrived in the Americas in 1502 (BECKLES 2002, 47), and for the next 270 years, "the trade and slavery itself were legal everywhere in Europe and the Americas (HOWARD-HASSMANN 2007, 5). Slavery therefore, was not just an activity of private members without institutional backing. The state encouraged and benefited from it through legislation. It was an incredibly profitable endeavour that supported America's economy at its infancy (NEUBORNE 2003). Also, while a lot of emphasis has been laid on the predominant nature of slavery in the southern part of the United States, the practice was not alien to the north. Many atrocities against slaves, though less pronounced, were equally committed against slaves in the north. (FARROW ... 2006, 62).

This is where the libertarian case made by Block for reparation becomes defective. While he feels that Horowitz and many other critics have not successfully countered the case for reparation, what he advocates is an understanding of slavery as a form of injustice by some members of the society against fellow men, which needs to be corrected. In that case, wherever it can be proven that $\mathrm{X}$, or his forbears $\checkmark$ engaged in slave-holding against $\mathrm{Y}$ or his forbears, reparation must be made. Under Ecapitalist principles he argued, the fact of death does not erase one's liability or Eentitlement (BLOCK 2002, 56-57). This approach however, establishes guilt in principle without repairing much. This is because by ignoring the institutional nature 
of slavery and the attendant discrimination and deprivation, the class of deserving beneficiaries become extremely narrowed and incapable of addressing the manifest gap it has created between blacks and whites over the decades. Looking for direct descendants has the tendency to diminish the proper appreciation of the depth of slavery. Individuals no doubt, are the ones involved, but they also represent a race of many different but related societies, which were the deliberate targets of slave traders. It is within this holistic understanding that the merit or otherwise of the reparation argument must be considered.

Block's argument though, has a limited aim, which, in a deontological sense is about atoning for an unjust act and not necessarily making the victim better. In his response to Horowitz's claim that wealthy blacks such as Oprah Winfrey do not need reparation because they have become successful. Block says that advocates of reparation "do not claim a transfer of wealth on the grounds that blacks are poorer than whites; they do so out of(somewhat misguided) claims of justice. Is it not possible that rich people can be oppressed? It seems to be Horowitz's argument that this cannot occur; it deserves to be characterized and rejected as the "Oprah Winfrey's fallacy" (BLOCK 2002, 61).

Much has also been made out of the difficulty involved in determining the extent of deprivation suffered, and its implication for the payment of what is justifiably due. But, expected difficulty is not in itself a negation of the rightness of reparation. Also, it is an argument that limits the payment of reparation to monetary compensation of victims. While it may be necessary to pay cash, there are many other social reforms and policies that would go a long way if targeted at the disadvantaged black nations and black-Americans with lower prospects of living meaningful lives owing to years of disadvantages.

\section{The Moral Basis of Slavery Reparation}

The case for reparation has been made on a number of grounds. One of them includes the population loss incurred from about 1445 to 1870 . The estimated figure of slaves taken, though conflicting and varying, has been put between a conservative estimate of 12 million (THIPANYANE 2003, 36), 20 million (GIFFORD 1996, 1) and 100 million (CHIKOTI 2001). The massive loss to Africa was not only colossal in terms of numerical worth; it is made more critical by the fact that it was composed of able-bodied young men and women (RODNEY 2000, 105). The shipping away of the agile and able-bodied brought in its wake drastic population reduction and attendant economic loss. Another argument for reparation centers on capital accumulation. The point being canvassed is that Europe and America benefited immensely from free labour of the slaves. Beyond that, even at the point of freedom,

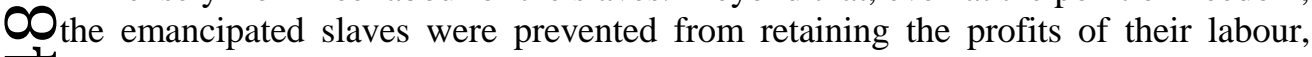
$\checkmark$ thereby depriving them of the empowerment needed immediately after their freedom (DARITY and FRANK 2005, 335).

Beyond that however, there is a need to harp on the immorality of the kind of slavery under consideration here, lest reparation becomes a kind of atonement for 
unfair trade, in the mould of sharp practices that sometimes characterize market deals. When one talks about trade, it connotes an idea of two or more people divided along the lines of buyer(s) and seller(s) mutually coming into an agreement for commodities that are to be exchanged for cash, or in the case of barter, for other commodities. But trade, in the mould of hiring mercenaries, some of them locals, to capture able-bodied persons packed into crates for transfer into places where they were made beasts of burden cannot be merely understood as unfair trade in which the victim expects compensation for collateral damage. In the view of MKO Abiola, it was an act designed to rob fellow men of their self-worth and dignity, to such an extent that their intrinsic value became measured by how well they can till the soil, clear bushes or hew down trees. It was a life whose standard was well below that of pets, such that using the term 'dehumanization' may not properly capture the level of degradation the slaves suffered (see AGHALINO 2000, 8).

For all the horrors and evils of the Holocaust, it must be said that the Nazis were primarily set out for extermination (AUSTEN 2003). The African slave on the other hand was a tool, which like the hoe or plougher must be kept efficient for as long as it remained expendable. That is why on the scale, slavery is worse than outright mass murder. The moral question also has to do with what Karenga (2001) refer to as "intentionality". Slavery is a deliberate, intensive and an institutionalized act of dehumanization unleashed by man on fellow man, on the basis of a false sense of racial superiority and economic gain.

Those slave merchants who shuttled between Africa, Europe and America may conveniently be described as involved in trade with business concerns and individuals who made up the market where those slaves were sold. After all, not all European and American slave owners came shopping in Africa. It is only in that sense that we can properly talk of trade (definitely of a different kind). Even at that, the long, sad episode of slavery remains the peak not only of human exploitation but also that of extended annihilation. On this basis, it must be said and quickly too, that no amount of compensation can adequately atone for the quantum of suffering experienced by Africans. Reparation at best, can only serve as a symbolic acceptance of guilt, with the purpose of mitigating the ill-effects of a better-forgotten era.

One moral argument that has also been advanced in defence of reparation is the violation of the harm principle. According to Peter Osimiri (2012, 169), harm involves the unjustifiable and intentional imposition of damage, injury or loss on an individual or group of individuals. we take this as a working definition, since harm can occur even without deliberate intention. What Osimiri seems to be highlighting is that slavery constitutes a grievous harm not only by virtue of its consequence but also by its intentional nature. Relying on the arguments of J.S. Mill (1974) and Thomas OPpogge \{2002), Osimiri argued that the idea of justice requires that harm not be $\checkmark$ visited on another even at the extreme demonstration of one's liberty. That is why a gdibertarian thinker like Robert Nozick would argue that stealing, defrauding, ¿enslavement and acts of such sort negates the idea of entitlement while demanding rectificatory justice (1974:152). Indeed, as McCarthy has argued, the principal moral 
intuition behind the idea of reparations is easy to grasp. If one agent has wrongfully harmed another, then the perpetrator has a prima facie moral obligation to repair, so far as possible, the damage to the victim (MCCARTHY 2004, 750).

The force of the moral arguments for reparation I perceive, are cogent enough to render a further obfuscation of the matter needless. That is why one regards the metaphysical argument for reparation of little force at this point. R.O. Badru (2010, 67-78), largely relying on the harm principle, marshaled a plausible case for reparation. Not satisfied however, he sought a reply to the trans-generational question by delving into religious and metaphysical arguments to drive home the point that contemporary Africans, by virtue of their belief in spatio-temporal continuity between the world of the physical and spiritual, and the attendant link between the ancestor and progenitor; are entitled to rectificatory claims on behalf of the dead. By recoiling into the shell of primordial speculation however, Badru takes the mutually agreeable platform of morality away, seeking to drag the perpetrator into a relativistic and speculative terrain that permits the latter to equally seek his own indulgence. Besides, it divorces the reparation argument from its existential warrant, which lies in its immense contribution to the underdevelopment of Africa till date. For emphasis, the moral arguments to us appear tenable without the vitiating effect of metaphysical arguments.

\section{Contemporary Africa and the Quest for Reparation}

Having made the point that the demand for reparation is both moral and justified, the next logical thing to do is to make a case for acceptable modalities of effectuation - a process whose complexity, even the most ardent proponent of reparation cannot deny. There is a need for caution however, in proceeding to such a stage, not the least because persuasive as the justifications are, they do not in themselves compel the West to take the necessary steps. What is most obvious is that while no Western nation today will justify slavery or slave trade, atoning for the negative consequences of its past practices has been met with utmost reluctance bordering nearly on outright denial. What this suggests then, is that while morality may form a large part of the ingredients of modern governance and international politics, it is not in itself a sufficient cause for action. Many nation-states today undoubtedly weigh the moral implications of decisions and actions, but such decisions are more easily taken when the dictates of morality coincide with interest. If this position is true, it implies then, that certain other conditions have to be met in order for reparation to become a reality. My concern in this section is to examine what condition is most conducive for the payment of reparation to African states in a way that is meaningful and beneficial. I suggest then, that beyond making a moral case, a realist understanding by African nations of what it takes to advance an interest at the level of international

Srelations among states is required. This suggestion is borne out of the further belief onthat the issue of reparation is significantly political. It is therefore erroneous to $\approx$ contemplate a strict bifurcation of the moral and political as if they always run on 
parallel lines. There are, in many cases, points of intersection. To this end, moral abstractions must find a complement in concrete power relations (GEUSS 2008, 23).

\section{Reparation and Realism}

Realism in political philosophy assumes that power is the primary end of political action whether in the domestic or international arena (MOSELEY 2006). It explains power from a realistic viewpoint and asserts that domestically, politicians strive to maximize their power while states do the same on the international arena. The argument is that the relations between self-seeking political entities are necessarily amoral, and it finds classical defense in Hobbes' The Leviathan and Machiavelli's The Prince.

Political realism is not necessarily immoral, neither is it unaware of the moral significance of political decision. What it does, while noting the tension between the moral and the political is to maintain that universal moral principles cannot be applied to the actions of states in their abstract universal formulation, but that they must be filtered through the concrete circumstances of time and place (MORGENTHAU 1978, 5). The political realist rejects the imposition of standards of thought on the political sphere while not denying them. He simply refuses to align moral aspiration with those that govern relationships, especially those of political natures in its descriptive elements. Political realism does not make much fuss about what 'ought' to be, it is concerned with what 'is'. Put differently, realism consists in ascertaining facts and giving them meaning through reason.

We live in a world in which morality is mouthed for the sake of political correctness and nothing beyond. What is moral and right is a function of interest and power. That is why the case can be made that the argument for reparation, in spite of its moral legitimacy faces so many hurdles to its attainment on one hand, and on the other involves serious implications that must be taken care of ahead of time by agitating nations.

It must be emphasized that though political realism is fundamentally amoral, its choice cannot be mistaken once morality conflicts with interest, Thus, while it may be easy on the part of the individual to say that "justice be done even if the world perish", the state denies the elevation of moral disposition above national survival. Political morality must therefore be regulated with prudence - a virtue regarded as most supreme in politics.

What then are the implications of this realist attitude to the agitation for reparation? The first is that a realistic assessment makes reparation unlikely in spite of its moral merits. We first of all need to cast our minds back to the rough classification we attempted earlier. Since the cause of history has ensured that some blacks are now $\checkmark$ Parts of other societies while others have sovereign nations to which they belong, Exreparation is bound to have effects that are not exactly the same. Black Americans $\sim$ may not get reparation beyond the possible re-affirmation of the congressional apology of 2008, and a few reforms that would grant them better access to schools, 
workplaces, decent houses and health care; but the social disorder that growing inequality between blacks and whites is likely to breed, may be a very good reason for the American government to take more action. This is not to imply that making reparation to black Americans will come easy, or that such, if contemplated and effectuated, will totally address the challenges faced by blacks in many American communities. Any gain of reparation that is not preceded by the entrenchment of racial equality in the real sense is bound to be eroded with time, such that those responsible for slavery would have discharged themselves to a reasonable extent, of the moral burden, with the situation of blacks remaining the same or getting worse in the long-term. Reparation though necessary as atonement on the part of the perpetrators, goes beyond the apologetic gesture behind it. For the victim, the goal is to be recompensed and respected, such that at the least he comes at par with his fellow men. It is for this reason that the failure to put the clamour in logical sequence is not only self-defeating but also capable of worsening in the long-term, what presently obtains. The American government however, does not have the type of motivation just mentioned, in paying reparation to African and Carribean nations, although it can be said concerning the latter that some form of reparation will go some way in stemming illegal immigration into the U.S., a nagging national problem for the country. The incentive to pay reparation to African states is the least appealing, as they (African states) have neither the relevant attachment or proximity to Europe or America, nor the political and economic leverage capable of spurring the West into meaningful action. This situation though, is hardly surprising.

Africa today, in spite of its numerous resources contributes the least to the global economy. It also accounts for the greatest concentration of the world's poor. More significant is the fact that many of the continent's states are involved in one internal conflict or the other; a situation which has made most of the states unstable and at the brink of collapse. While some have identified imperialism as the cause of the present state of things, others point to poor leadership and the high level of corruption for which the continent has become notorious. I shall return to this causal controversy shortly, but it is apposite to mention here that the consequences of the present situation are less controversial. There is a consensus between the internalists and externalists that the continent is characterized by numerous indices of underdevelopment. It is on this basis one can reasonably infer that African nations in their present state cannot make an effective case for reparation. Even if they manage to do so, whatever benefit that accrues from such payment is likely to be eroded under the present condition. Numerous avenues, such as corruption, mismanagement and consumption-driven economies are likely to ensure that no tangible benefit results from reparation even if it gets paid.

Given the above, the pertinent question at this juncture is what needs to be 1 done by African states to strengthen their case for reparation and enjoy the benefit of onsame if successfully achieved. The answer to this question, I propose, lies in Africa's

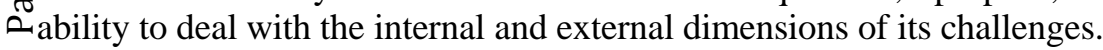




\section{Contemporary African Leadership and Reparation}

One cannot dispute the fact that Africa's past has a role to play in its present predicament, even if we disagree on the extent. It is equally self-evident that the continent's underdevelopment, at least as can be witnessed in many of its postindependent states, has continued in a frightening pace with very little to suggest there is hope for a halt. African underdevelopment is like a coin, which has two sides to it (OYEKAN 2008). On the one hand is the internal problem of corruption, poor leadership, strife and dictatorship among others (see AYITTEY 1992). On the other hand is the external dimension of the problem, which is imperialism. Of course, these two dimensions of the problem are sometimes interwoven, for some of the crises on the continent for instance, are products of the divisive structures left behind by colonial powers. Most conflicts on the continent emanated from the problems created by colonial administrative structures which at the time proved efficient for the management of subjugated societies but are no longer fitting in sovereign states. To put it more clearly, African underdevelopment is a product of imperialism and the internal problems of leadership and corruption which must be dealt with if the continent is to develop.

Paradoxically, dealing with these challenges requires effective and good leadership, of which the continent is in acute shortage (FALAIYE 2012). In most African countries today, leadership emerge from a parody of true democratic processes, thereby conferring legitimacy on elites who are far detached from the needs and aspirations of the people. Added to the absence of structures and institutions needed for equipping citizens for leadership roles and positions, what obtains often is both the lack of will and skills requisite for meaningful leadership. What the current mass of poor leadership in the continent has bred is hunger, illiteracy, conflicts and low life-expectancy among others.

Reversing the trend requires therefore, effective leadership equipped and committed to the task of development by consciously taking proactive steps in ending the continent's slide into the crater of poverty and desolation. It requires also, understanding how to walk the thin line of inter-dependence in an age of globalization without being appendages to foreign powers. This will further require a huge investment in human capital as he most important factor in the process of selfreliance. Addressing the challenge of leadership is important for African development on the one hand, and for the reparation question on the other for two reasons.

The first is that it places the continent in a better stead to negotiate for commensurate compensation. A continent struggling for survival is not likely to reject whatever is dangled at it by the west. In fact, many African nations clamour for Mreparation with the hope of making use of whatever it offers to ameliorate their

Simmediate problems. A continent that is more relevant globally however, can make on louder case and negotiate not in a recumbent position but across the table. Second, $\widetilde{\sigma}_{\text {it }}$ prevents a situation whereby the possible gains of reparation get eroded through imperial conduit pipes in the form of trade agreements with foreign countries. In 
addition, we live in a global age where integration is happening with more intensity. This suggests that nations of the world would need each other more than ever before. A developed Africa would therefore have much more to offer the world and therefore exploit its relevance as a bargaining tool in the quest for slave reparation. This of course is not to say that the argument lacks merit on moral grounds. What is being said is that in this age of political realism, power and interest provide quicker and better answers than feeble moral protestation. It is for this reason that the moral case must be supplemented with an approach that compels prudence from the parties concerned.

A developed Africa does not detract from the need for reparation. To understand this point, it is important to refer in one vein to the "Oprah Winfrey's fallacy" earlier discussed, and mention in another vein, that reparation is not a form of aid. Aid may not be necessary where there is development. Africa's development on the other hand, does not vitiate the case for reparation. Aids are provided on compassionate grounds by affluent nations to weak ones without claiming responsibility for such weakness. In other words, aid is often a voluntary response to the predicament of fellow humans who though may be distant, live under conditions that are considered humanly indecent and therefore deserving of assistance, especially when feasible. Reparation on the other hand is an obligation arising from past injustice, with little or no bearing on the status of the victim.

\section{Conclusion}

In this paper, I have tried to examine the arguments for reparation, and suggested that in spite of the numerous counter-arguments against it, there are very strong factual and moral reasons why black people, whether in Africa, the Caribbean or within the United States deserve to be paid reparations. I have also noted however, that the case for reparation is not exclusively a moral one. The political dimension to it requires a realist understanding, especially on the part of African states. I therefore proceeded to maintain that until African states address in large parts their numerous problems which are both internal and external in nature, making a plausible and rewarding case for reparation may remain a tall order. Central to this is the need to address the leadership deficit across the continent through the strengthening of those institutions that ensure effective and responsible leadership. It is under this condition that Africa can begin to work towards self-sustenance and less dependence on foreign nations for survival. It was argued that a more developed Africa with a greater global stake has more leverage to demand tangible reparation and maximize same for the benefit of its people. Effective leadership in Africa is in itself not an automatic guarantee that reparation will come easy, but it is one without which the continent can neither $\checkmark$ make a bold case nor survive for long. 
Filosofia Theoretica: Journal of African Philosophy, Culture and Religions

\section{Relevant Literature}

1. AGHALINO, Samuel O. "The Quest for Reparation to Africa and Africans in Diaspora." [African Journal of Social and Policy Studies], Vol. 1 No. 2, Pp. 713, 2000. Paperback.

2. AKE, Claude. [Democracy and Development in Africa], 1996. The Brooking Institution: Washington. Paperback

3. ARTHUR, John. [Race, Equality and the Burden of History], 2007. Cambridge University Press: Cambridge. Paperback.

4. AYITTEY, George. [Africa Betrayed], 1992. St. Martin's Press: New York. Paperback.

5. BADRU, Ronald. O. "Reparations for Africa: Providing Metaphysical and Epistemological Grounds of Justice to the Descendants of Dehumanised Generation." [Cultura: Journal of Philosophy of Culture and Axiology], Vol. VII, No. 2, Pp. 67-80, 2010. Web.

6. BECKLES, Hilary M. [Slave Voyages: The Transatlantic Trade in Enslaved Africans], 2002. UNESCO: Paris. Web.

7. BLOCK, Walker. "On Reparation for Black Slavery." [Human Rights Review], July-September, Pp. 53-73, 2002. Web.

8. BOXILL, R. Bernard. "A Lockean Argument for Black Reparation." [A Discussion Paper at the Meeting of the Research Triangle Ethics Circle], 2003. Web.

9. BROOKS, R.L. [Atonement and Forgiveness: A New Model for Black Reparations], 2006. University of California Press: Los Angeles. Paperback.

10. CHIKOTI, Georges. [World Conference Against Racism, Racial Discrimination, Xenophobia and Related Intolerance], 2001. Web. Retrieved from http://www.un.org/WCAR/statments/angolaE.htm on 24/01/2014.

11. DARITY, William and Frank, Davia. "The Economics of Reparation." IAfrican Americans in the US Economy, Cecilia A. Conrad, John Whitehead, Patrick Mason, and James Stewart Eds.], Pp. 334-338, 2005. Roman \& Littlefiled Publishers: Lanham, MD. Paperback.

$\approx_{12 .}$ FANON, Frantz. [Wretched of the Earth, Richard Philcox, Trans.], 1966. Groove Press: New York. Paperback. 
13. FALAIYE, Muyiwa. [A Philosopher Interrogates African Polis: How Can We Get it Right?] 2012. Inaugural Lecture, University of Lagos: Lagos. Paperback.

14. FARROW, Anne, Joel Lang, and Jenifer Frank. [Complicity: How the North Promoted, Prolonged, and Profited from Slavery], 2006. Ballantine Books: New York. Paperback.

15. FEAGIN, J. R. "Documenting the Cost of Slavery, Segregation, and Contemporary Racism: Why Reparation Are in Order for African Americans." [Harvard Black Letter Law Journal], Vol. 20, Pp. 49-81, 2004. Web.

16. GROSSMAN, James. [A Chance to Make Good: African Americans: 19001929], 1997. Oxford University Press: New York. Paperback.

17. HOROWITZ, David. [Uncivil Wars: The Controversy over Reparations for Slavery], 2002. 2002. Encounter Books: New York. Web.

18. HORWARD, - Hassman, E. R. [Reparations for the Slave Trade: Rhetoric, Law, History and Political Realities], 2007. Working Paper. Web.

19. KANE, Gregory. “'”hy the Reparation Movement Should Fail”. [University of Maryland Law Journal of Race, Religion, Gender and Class], Vol. 3 Issue 7, Pp. 189-208, 2003. Web.

20. LEWAN, Todd \& Dolores Barclay. "Inquiry: Black Landowners Cheated." [Sunday Herald]. Durban, N.C: December 9, A3, 2001. Web.

21. LORD, Gifford. "'Slavery: Legacy." [Hansard, House of Lords of the British Parliament], $14^{\text {th }}$ March, 1996. Web.

22. MAULANA, Karenga. [The Ethics of Reparations: Engaging the Holocaust of Enslavement]. 2001. Web.Retrieved from: http://www.africawithin.com/karenga/ethics.htm; On 12/062015.

23. MCCARTHY, T. "Coming to Terms with Our Past, Part II: On the Morality and Politics of Slavery." [Political Theory], Vol. 32, No. 6, Pp. 623-648, 2004. Paperback.

24. MILL, John S. [On Liberty. G. Himmelfarb, Ed.], 1974. Penguin: New York. Paperback.

๘ू25. MORGENTHAU, Hans. [Politics Among Nations: The Struggle for Power and Peace], 1978. Alfred A. Knopf: New York. Paperback. 
Filosofia Theoretica: Journal of African Philosophy, Culture and Religions

26. MOSELEY, Alexander. [Political Realism], Web. Retrieved from: www.iep.utm.edu/polreal On 19/06/2016.

27. NEUBORNE, Burt. "Holocaust Reparation Litigation: Lessons for the Slavery Reparation Movement." [New York University Annual Survey of American Law], Vol. 58, Issue 4, Pp 615-622, 2003. Web.

28. NOZICK, Robert. [Anarchy, State and Utopia], 1974. Blackwell: Oxford. Paperback.

29. OGLETREE, C. J. "Repairing the Past: New Efforts in the Reparation Debates in America. Harvard Civil Rights Civil Liberties." [Law Review], Vol. 38, Pp. 279-320, 2003. Web.

30. ONIGBINDE, Akinyemi. [Development of Underdevelopment: Conceptual Issues in Political Economy], 2003. Frontline Publishers: Ibadan. Paperback.

31. OSIMIRI, Peter. "Africa, the West and the Search for Rectificatory Justice." [A Study in African Socio-Political Philosophy: Essays in Honour of Professor Muyiwa Falaiye], Pp. 165-180. 2012. University of Lagos Press: Lagos. Paperback.

32. OYEKAN, Adeolu. "The African Notion of Education as a Panacea to Leadership Problems." [A paper presented at the 2008 PEAN Conference],Olabisi Onabanjo University: Ago-Iwoye. Lecture-Text.

33. POGGE, Thomas. [World Poverty and Human Rights: Cosmopolitan Responsibilities and Reform], 2002. Polity: Cambridge. Paperback.

34. RALPH, Austen. "The Jewish Holocaust as a Model for African-American Slave Trade Discourse: History, Politics and Memory." [African and Black Nationalism: A Discourse in African and Afro American Studies, Muyiwa Falaiye, Ed.], Pp. 179-208, 2003. Foresight Press: Lagos. Paperback.

35. RODNEY, Walter. [How Europe Underdeveloped Africa], 2000. Bogle-L Ouverture Publications: London. Paperback.

36. THIPANYANE, Tseliso. "Current Claims, Regional Experiences, Pressing Problems: Identification of the Salient Issues and Pressing Problems in an African Post-Colonial Perspective." [Human Rights in Development: Reparation, Redressing Past Wrongs, George Ulrich and Louise Krabbe Boserup, Eds.], Pp. 33-55, 2003. Kluwer Law International: The Hague. Paperback. 
Vol. 5 No. 1

January - June, 2016

37. TRACINSKI, W. Robert. "'America's 'Field of the Blackbirds: How the Campaign for Reparation Perpetuates Racism." [Journal of Sociology], Pp. 145-157, 2002. Web.

38. WASHINGTON, Booker. [Up from Slavery], 1967. Kessinger Publishing co: Montana. Paperback.

39. WINBUSH, Raymond. "'The Earth Moved: Stealing Black Land in the United States." [Should America Pay? Slavery and the Raging Debate Over Reparation, Raymond Winbush, Ed.], 2003. Harper Collins: New York. Paperback. 